\title{
Importance of timing of panel exposure on the competitive outcome and succession of sessile organisms
}

\author{
Kanavillil Nandakumar* \\ Amakusa Marine Biological Laboratory, Kyushu University, Tomioka, Amakusa, Kumamoto-ken 863-25, Japan
}

\begin{abstract}
Competitive interaction among sessile organisms was studied by suspending PVC (polyvinylchloride) panels in 4 different seasons at Tomioka Bay, south Japan. Panels were suspended in such a way that only 1 side received direct sunlight. Panels were monitored by intermittent photography for a maximum period of $14 \mathrm{mo}$. On the sunlit side of the panels, 35 species belonging to 8 taxonomic groups were encountered. A total of 7980 interspecific interactions among these organisms were monitored and the competitive relationships among them were ascertained. Competitive relationships on panels suspended in November 1991 (autumn) and August 1992 (summer) and monitored until December 1992 resulted in a simple hierarchy. On the other hand, panels suspended in February (win. ter) and April 1992 (spring) and monitored until December 1992 did not result in a hierarchy. Observation of panels after 4 mo of initiation in all 4 seasons showed different levels of competitive dominance for the same set of species. At the end of the study, the colonial ascidians Diplosoma mitsukurii and Didemnum moseleyi dominated on the panels initiated in autumn and summer, whilst no such hierarchy could be observed on the panels initiated in winter and spring. However, at the end of 4 mo of initiation, herarchy could be detected in all 4 seasons. The branching bryozoan Zoobotryon pellucidum occupied the topmost position in the hierarchical order in panels initiated in winter and spring when observed after 4 mo of initiation. Reversal of organisms' positions in the hierarchical order with the change in panel initiation season could be observed on the panels at the end of study. The results showed the competitive interactions among these organisms, the time of panel initiation and/or the initial colonizers of the panel surfaces which significantly affected the subsequent species composition and the succession of species on these panels.
\end{abstract}

KEY WORDS: Time of initiation PVC panels Space competition - Sessile organisms

\section{INTRODUCTION}

Interspecific competition for space and food among subtidal and intertidal organisms has been widely studied by many workers (Dayton 1971, Harger 1972, Stebbing 1973a, b, Jackson \& Buss 1975, Buss 1979, Jackson 1979, 1983, Benayahu \& Loya 1981, Underwood \& Jernakoff 1981, Logan 1984, Sebens 1985, Best \& Thorpe 1986, Okamura 1986, Harvell et al, 1990, Steneck et al. 1991). Among hard-bottom sessile organ-

\footnotetext{
- Present address: Water and Stream Chemistry Laboratory, Indira Gandhı Center for Atomic Research, Kalpakkam, Tamil Nadu 603 102, India
}

isms, as vegetative growth proceeds, they contact each other, and one of the following outcomes occurs: (1) overgrowth of one species by the other or (2) cessation of growth along the margin of contact between the species. The former process is termed as overgrowth and the latter as standoff (Buss 1990).

Overgrowth interaction among sessile organisms has been described as an important determinant of distribution and abundance of organisms at a given locality (Connell 1961a, b, Dayton 1971, Lang 1973, Stebbing 1973a, b, Sutherland 1974, Jackson 1977, Osman 1977. Paine 1984, Underwood \& Anderson 1994) The outcome of competitive interaction has been reported to be influenced by many factors such as colony morphol- 
ogy, vertical relief, angle of contact, colony size, presence of predators and genetic variation of interacting colonies (Buss 1980, 1990, Grosberg 1981, Jackson 1983, Nandakumar \& Tanaka 1993, 1994a, b, Turner \& Todd 1994). While studying the spatial relationship among encrusting organisms in the subtidal zone of New England, USA, Sebens (1986) reported that the outcome of interactions was not significantly correlated with the warm or cold seasons. Sutherland (1974) reported the existence of multiple stable points or climaxes of succession of fouling communities on panels initiated in different periods of a year. However, to date, comprehensive studies addressing the effect of timing of substratum exposure on the competitive dominance of subtidal sessile organisms appears to be sparse.

Underwood \& Anderson (1994), while studying the effect of types of substratum on the development and diversity of fouling organisms, found that faunal composition depends on the type of substratum, the timing of panel immersion and the initial colonizers of panel surfaces. However, Greene \& Schoener (1982) and Anderson \& Underwood (1994) found that the degree of diversity among fouling organisms becomes narrow over time

Many earlier workers described the competitive relationships among hard-bottom sessile organisms as following either the pattern of network or of hierarchy (Buss \& Jackson 1979, Kay \& Keough 1981, Quinn 1982, Russ 1982). The usual interference phenomenon observed among sessile organisms is the simple overgrowth of one of the interacting species. Therefore, the degree of competence of a sessile species is monitored by its capacity to overgrow its neighbors (Rubin 1982, Karande \& Swami 1988). On hard substrata, organisms can be classified according to their body plan (i.e. solitary, colonial) (Woodin \& Jackson 1979, Greene et al. 1983). Colonial organisms were considered as superior competitors to the solitary types that are usually the initial colonizers of the substratum (Nandakumar et al. 1993). The importance of initial colonizers on subsequent community development was studied by Sutherland \& Karlson (1977), who also suggested that the composition of a fouling community depends on the timing of panel suspension and the types of initial colonizers. These facts suggest that competitive relationships among sessile organisms may vary with the timing of substratum exposure and the nature of the initial colonization. While reporting the influence of competitive ability on the choice of habitat in marine invertebrates, Grosberg (1981) noted that very little information is available on the ecological and evolutionary relationships among factors such as seasonal recruitment, substratum selection and post-settlement events. The present study was carried out to monitor the importance of timing of substrata initiation on the competitive dominance in sessile organisms.

\section{MATERIALS AND METHODS}

Study area and panel suspension. This study was conducted in Tomioka Bay, south Japan $\left(32^{\circ} 33^{\prime} \mathrm{N}\right.$, $130^{\circ} 02^{\prime} E_{i}$ Fig 1). A description of the study site is given elsewhere (Nandakumar et al. 1993). Four polyvinylchloride (PVC) panels $(25 \times 25 \times 0.3 \mathrm{~cm})$ were suspended at $1 \mathrm{~m}$ depth from a floating pier anchored about $10 \mathrm{~m}$ away from the shore in each season. Panels were exposed in the months of November 1991 (autumn), February 1992 (winter), April 1992 (spring) and August 1992 (summer). All panels were monitored photographically until December 1992. Photographs of a $10 \times 10 \mathrm{~cm}$ area at the center of the panels were taken at fortnightly intervals until the end of the study (for details of photosampling see Nandakumar et al. 1993); altogether, 193 photographs were taken and analyzed. Weekly fluctuations in seawater temperature at the study site are given in Fig. 2.

Panels were suspended vertically in such a way that only 1 side of the panels received direct sunlight. However, in the present paper only interactions occurring on the sunlit faces were considered. Since there was no significant variation with respect to the total area cover (1-way ANOVA, $p>0.35$ ), number of species (1-way ANOVA, $p>0.36$ ), species composition and sequence of colonization among the 4 panels suspended in each month, the respective 4 panels of each month were

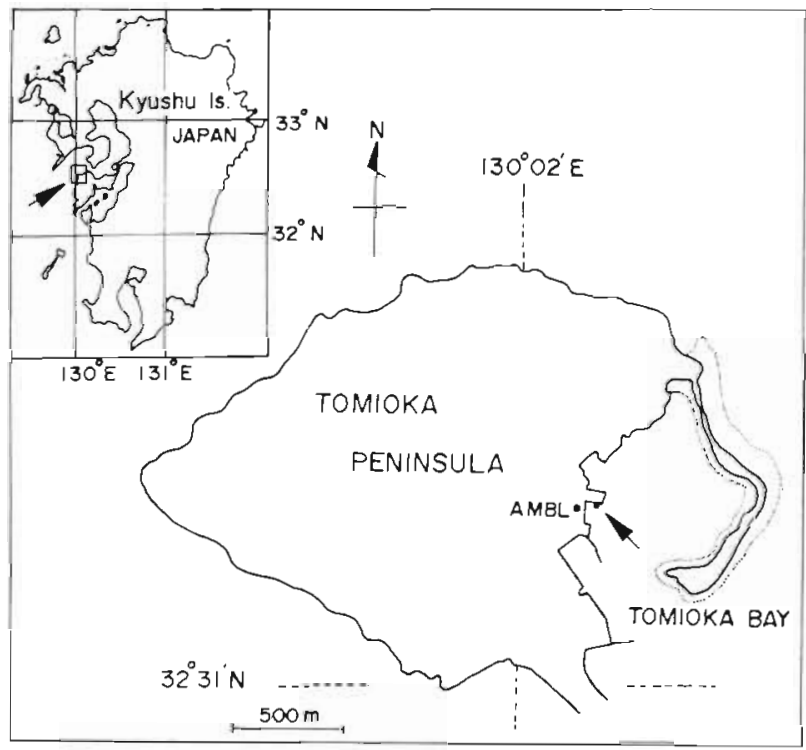

Fig. 1. Map of study area showing the sampling point 
grouped together before making species interaction matrices, hierarchical orders and further statistical analysis. For preparing the interaction matrices and orders of hierarchy, species which covered more than $1 \%$ of the observed panel area $(10 \times 10 \mathrm{~cm})$ at least once during the many repeated observations were included.

Measurement of species interaction. The merits of repeated panel observation in overgrowth interaction studies of sessile invertebrates have been shown by Schoener \& Greene (1981) and Nandakumar et al. (1993). In the present study, repeated observation of the fixed panel area provided accurate assessment of the outcomes of interaction. As in earlier studies (Rubin 1985, Lopez Gappa 1989, Nandakumar et al. 1993), in the present study 3 kinds of interaction outcome were monitored: win, loss and standoff. The winner of overgrowth interaction among colonial organisms was defined as the species showing an upward elevation of the growing edge over the other to the extent that it covers the opening of the zooid of other species (as in the cases of Acidia and Bryozoa). However, in other colonial organisms, such as sponges, simple elevation of the growing edge over the other was defined as a win for the former species. Wherever solitary organisms were involved, the upward elevation of colonial organisms over the solitary one or the settlement and growth of solitary species over the colonial one was considered as a win for the corresponding species. Standoff was considered as the cessation of growth along the margin of contact between colonies of different species. Each standoff interaction was monitored repeatedly to make sure that the cessation of growth along the margin of contact had actually occurred.

Since the entire study depended on photography, only the 2-dimensional growth of sessile organisms was considered. Where vertically growing organisms were involved, the interaction was considered only when contact between the attachment bases could be clearly seen in photographs (Sebens 1986). Shade effects of the vertically growing species were considered negligible; intraspecific interactions were not considered during this study.

Competitive relationships. The competitive relationships among sessile organisms were mainly grouped into 2 patterns: hierarchy (transitive relationship where Species 1 always wins over Species 2 and 3 , Species 2 always wins over Species 3; Buss 1980) and network (intransitive: Species 1 may or may not win over Species 2; Species 2 may or may not win over Species 3; and Species 1 may or may not win over Species 3; Buss 1980). In this study, species dominance was used as a relative measure to express the abundance of a species (with respect to the area cover) in comparison with others. However, the term competitive dominance of a species indicates significant competitive success (after statistical testing) of that species over others.

Residence time of species. Residence time (presence of species on panels) in months of major species was monitored on panels initiated in autumn and winter. This was done to improve understanding of the frequency of invasion and exclusion of the species from panels with respect to their time of immersion.

Data analyses. To determine competitive dominance, $\chi^{2}$ contingency test was applied (Sokal \& Rohlf 1987) to the outcome of interactions of each species pair. The null hypothesis was that there is an equal probability for win and loss measured as competitive ability between each pair of interacting species. Methods of $\chi^{2}$ analysis and judgment of the outcome are given in Nandakumar (1995). The results are given in the form of species interaction matrices.

\section{RESULTS}

\section{Species composition}

Altogether, 35 species belonging to 8 major taxonomic groups were recorded during this study. A few species could not be clearly identified from the photographs due to their close similarity to the related species; these were grouped together to form small subgroups. The list of species with their sub-groups and abbreviations are given in Table 1

\section{Fluctuation of species number}

The fluctuation in number of species on panels initiated in 4 seasons are given in Table 2 . The panels initiated in autumn, spring and summer were colonized faster (within 2 to 3 mo of submersion) than the ones

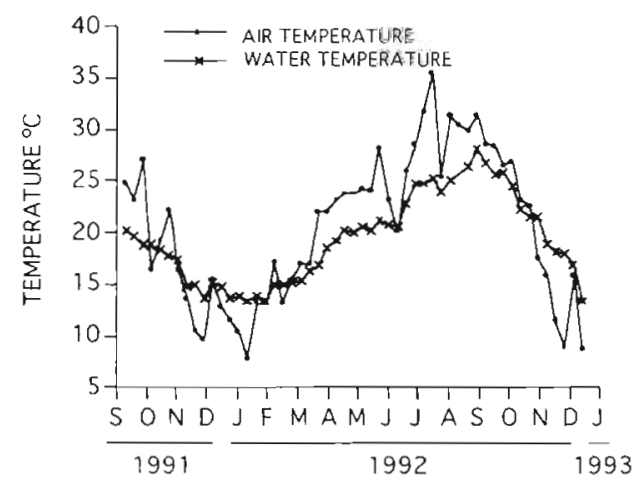

Fig. 2. Weekly fluctuation of seawater and air temperatures at the study area during the study period 
Table 1. List of sessile organisms encountered during the study with their groupings and abbreviations

\begin{tabular}{|c|c|}
\hline $\begin{array}{l}\text { Sl. no./Taxon. group } \\
\text { Species }\end{array}$ & Abbreviation \\
\hline $\begin{array}{l}\text { 1. Algae } \\
1 \text { Enteromorpha linza } \\
2 \text { Enteromorpha sp. }\end{array}$ & ES \\
\hline $\begin{array}{l}3 \text { Ulva faclata } \\
4 \text { Ulva pertusa }\end{array}$ & US \\
\hline 5 Colpomenia sinuosa & $\mathrm{CS}$ \\
\hline $\begin{array}{l}6 \text { Ectocarpus sp. } \\
7 \text { Scytosiphon lomentaria } \\
8 \text { Petalonia facia } \\
9 \text { Lomentaria sp. } \\
10 \text { Binghamia californica } \\
11 \text { Champia bifida }\end{array}$ & $\mathrm{AC}$ \\
\hline $\begin{array}{l}2 \text { Coelenterata } \\
12 \text { Obelia dichotoma }\end{array}$ & OD \\
\hline $\begin{array}{l}3 \text { Porifera } \\
13 \text { Haliclona sp. } \\
14 \text { Sponge species } 2 \\
15 \text { Sponge species } 3\end{array}$ & $\begin{array}{l}\mathrm{HS} \\
\mathrm{S} 2 \\
\mathrm{~S} 3\end{array}$ \\
\hline $\begin{array}{l}4 \text { Polychaeta } \\
16 \text { Hydroides elegans } \\
17 \text { Serpula kaempreri } \\
18 \text { Spirorbid worms }\end{array}$ & SW \\
\hline $\begin{array}{l}5 \text { Bryozoa } \\
19 \text { Schizoporella serialis } \\
20 \text { Watersipora subovoidea } \\
21 \text { Celleporaria aperta } \\
22 \text { Zoobotryon pellucidum } \\
23 \text { Bugula neritina } \\
24 \text { Bugula californica }\end{array}$ & $\begin{array}{l}\text { SS } \\
W S \\
C A \\
Z P \\
B N \\
B C\end{array}$ \\
\hline $\begin{array}{l}6 \text { Molluscs } \\
25 \text { Mytilus varidis }\end{array}$ & MV \\
\hline $\begin{array}{l}7 \text { Crustacea } \\
26 \text { Megabalanus rosa } \\
27 \text { Balanus trigonus }\end{array}$ & $\begin{array}{c}\text { MR } \\
\text { BT }\end{array}$ \\
\hline $\begin{array}{l}8 \text { Ascidia } \\
28 \text { Didemnum moseleyi } \\
29 \text { Diplosoma mitsukurii } \\
30 \text { Botryllus schlosseri } \\
31 \text { Botrylloides sp. } \\
32 \text { Perophora japonica } \\
33 \text { Aplidium pliciferum } \\
34 \text { Styela plicata } \\
35 \text { Lissoclinum sp? }\end{array}$ & $\begin{array}{l}\text { DM } \\
\text { DT } \\
\text { BS } \\
\text { BO } \\
\text { PJ } \\
\text { AP } \\
\text { SP } \\
\text { LC }\end{array}$ \\
\hline
\end{tabular}

initiated in winter. The number of species differed significantly (ANOVA, $p<0.05$ ) on these panels during the first 4 mo after submersion, but as the time elapsed, the difference became insignificant (Table 2). The trend of colonization over time on panels initiated in different seasons showed faster colonization during the first 4 mo after immersion than during the later periods (Table 3 ). Panels submerged in winter were
Table 2. Changes in the number of species over time on panels initiated in different seasons. Spearman's rank correlation coefficient was used to test the pace of colonization on the same set of panels over time in arbitrary time intervals. In each of 4 seasons 4 panels were observed over definite time intervals (see 'Materials and methods'). Figures in parentheses show the number of times each panel was observed and thus the sample size (n) for the analysis. "-Highly significant $(p<0.01)^{*} \cdot$ significant $(p<0.05)$; ns: not significant $(p>0.05)$

\begin{tabular}{|llcr|}
\hline Season & \multicolumn{3}{c|}{$\begin{array}{c}\text { Immersion period } \\
4-8 \mathrm{mo}\end{array}$} \\
& $\begin{array}{c}8 \mathrm{mo}- \\
\text { end of study }\end{array}$ \\
\hline Autumn & $0.9(8)^{\circ}$ & $-0.3(6) \mathrm{ns}$ & $-0.4(6) \mathrm{ns}$ \\
Winter & $1.0(8)^{\circ} \cdot$ & $-0.1(6) \mathrm{ns}$ & $1.0(2) \mathrm{ns}$ \\
Spring & $0.7(7)^{\circ}$ & $-0.7(4) \mathrm{ns}$ & \\
Summer & $0.8(8)^{\circ}$ & & \\
& & & \\
\hline
\end{tabular}

initially colonized by the brown alga Colpomenia sinuosa which in turn delayed the colonization of organisms such as colonial ascidians. Even the ascidians that settled could not survive as long as they did on. the panels submerged in autumn.

\section{Residence time}

Residence time of major sessile organisms encountered during autumn and winter is given in Table 4. There was no significant difference in residence time between solitary and colonial organisms on panels initiated in either of the 2 seasons (ANOVA, $p>0.05$ ). However, among the tested organisms, serpulid worms showed maximum residence time in both seasons (Table 4). The short residence time emphasized the

Table 3. Changes in number of species over time on panels initiated in different seasons. Species number on panels (suspended in different seasons) after fuxed time intervals $(2,4$ and 8 mo after initiation) was compared using 1-way ANOVA.

\begin{tabular}{|c|c|c|c|c|c|c|}
\hline Seasons & df & $2 \mathrm{mo}$ & $\mathrm{df}$ & $4 \mathrm{mo}$ & $d f$ & $8 \mathrm{mo}$ \\
\hline $\begin{array}{l}\text { Autumn } x \\
\text { Winter }\end{array}$ & 1.6 & $\begin{array}{l}F=162.0 \\
p=0.0001\end{array}$ & 1,6 & $\begin{array}{l}F=6.153 \\
p=0.0478\end{array}$ & 1,6 & $\begin{array}{l}F=1.882 \\
p=0.2192\end{array}$ \\
\hline $\begin{array}{l}\text { Autumn } \times \\
\text { Spring }\end{array}$ & 1,6 & $\begin{array}{l}F=0.682 \\
p=0.4583\end{array}$ & 1,4 & $\begin{array}{l}F=13.33 \\
p=0.0217\end{array}$ & 1,4 & $\begin{array}{l}F=3.226 \\
p=0.1469\end{array}$ \\
\hline $\begin{array}{l}\text { Autumn } x \\
\text { Summer }\end{array}$ & 1,6 & $\begin{array}{l}F=0.857 \\
p=0.3903\end{array}$ & 1,6 & $\begin{array}{l}F=12.0 \\
p=0.0134\end{array}$ & & \\
\hline $\begin{array}{l}\text { Winter } \times \\
\text { Spring }\end{array}$ & 1,6 & $\begin{array}{l}F=15.698 \\
p=0.0074\end{array}$ & 1,4 & $\begin{array}{l}F=0.025 \\
p=0.8815\end{array}$ & 1,4 & $\begin{array}{l}F=0.828 \\
p=0.4144\end{array}$ \\
\hline $\begin{array}{l}\text { Winter } \times \\
\text { Summer }\end{array}$ & 1,6 & $\begin{array}{l}F=54.857 \\
p=0.003\end{array}$ & 1,6 & $\begin{array}{l}F=0.458 \\
p=0.5239\end{array}$ & & \\
\hline $\begin{array}{l}\text { Spring } \times \\
\text { Summer }\end{array}$ & 1,6 & $\begin{array}{l}F=0 \\
p=0\end{array}$ & 1,6 & $\begin{array}{l}F=0.533 \\
p=0.5057\end{array}$ & & \\
\hline
\end{tabular}


Table 4. Mean residence time of sessile organisms (in months) on panels suspended in November (autumn) 1991 and February (winter) 1992 and monitored until December 1992. \#: presence of species even at the end of the study

\begin{tabular}{|c|c|c|c|c|c|c|}
\hline \multirow[t]{2}{*}{ Species } & \multicolumn{3}{|c|}{ Autumn } & \multicolumn{3}{|c|}{ Winter } \\
\hline & Mean $\pm S D$ & Range & $(\mathrm{n})$ & Mean \pm SD & Range & (n) \\
\hline Diplosoma mitsukuni & $3.8 \pm 1.6$ & $2-6.5$ & (6) & $1.8 \pm 1.7$ & $0.5-5 \#$ & (9) \\
\hline Didemnum moseleyi & $2.9 \pm 2.1$ & $1-5.5$ & (4) & $3.4 \pm 2.9$ & $1-7 \#$ & (5) \\
\hline Botryllus schlosseri & $3.1 \pm 2.3$ & $1-6.5$ & (5) & $4.5 \pm 1.2$ & $3.5-6$ & (4) \\
\hline Botrylloides sp. & $2 \pm 0$ & 2 & (1) & $0.8 \pm 0.3$ & $0.5-1$ & (3) \\
\hline Lysoclinum sp. & $2.3 \pm 0.6$ & $2-3$ & (3) & $2 \pm 0$ & 2 & (1) \\
\hline Styela plicata & $4.4 \pm 2.3$ & $1-6$ & (4) & $6.9 \pm 0.6$ & $6-7.5 \#$ & (4) \\
\hline Balanus trigonus & $1.2 \pm 0.4$ & $1-1.5$ & (2) & $1.7 \pm 0.5$ & $1-2$ & (6) \\
\hline Zoobotryon pellucidum & $1.6 \pm 0.8$ & $1-3 \#$ & $(6)$ & $1 \pm 0$ & $1-1$ & (5) \\
\hline Watersipora subovoidea & $4 \pm 2$ & $2-6 \#$ & $(2)$ & $2.4 \pm 1.1$ & $1-3.5$ & (4) \\
\hline Celleporaria aperta & $4.7 \pm 2.1$ & $1-7$ & (5) & $1 \pm 0$ & 1 & (1) \\
\hline Bugula neritina & $3.3 \pm 2.3$ & $0.5-6$ & (6) & $1 \pm 0$ & 1 & (1) \\
\hline Bugula californica & $1.9 \pm 1.4$ & $0.5-3.5$ & (4) & $1.2 \pm 0.4$ & $1-2$ & (5) \\
\hline Serpulid worms & $7.6 \pm 2.8$ & $5-10 \#$ & (5) & $4.5 \pm 3.2$ & $0.5-8 \#$ & (6) \\
\hline Haliclona sp. & $2.9 \pm 1.8$ & $1-5$ & (5) & $2.8 \pm 1.4$ & $1-4 \#$ & (6) \\
\hline Colpomenia sinuosa & $2.4 \pm 1.2$ & $1-4$ & (5) & $26 \pm 0.4$ & $2-3$ & (5) \\
\hline
\end{tabular}

rapid invasion and exclusion of species from the panels in this locality.

\section{Fluctuation in species area cover}

\section{Autumn series}

Panels exposed in autumn were dominated initially by the algal complex and colonial organisms such as colonial ascidians and bryozoans. This was followed by the sponge Haliclona sp and serpulid worms. It could be seen that the period of dominance (with respect to the area cover of each colonial species lasted longer period (i.e. more than $4 \mathrm{mo}$ ) than those observed in panels initiated in other season (Figs. 3 to 6 ).

\section{Winter series}

These panels showed initial dominance of algae which extended for a period of $4 \mathrm{mo}$. The colonial organisms such as ascidians, bryozoans and sponges did not demonstrate as a long dominance period as they did in the autumn initiated panels.

\section{Spring series}

Panels initiated in spring showed dominance of solitary species such as barnacles

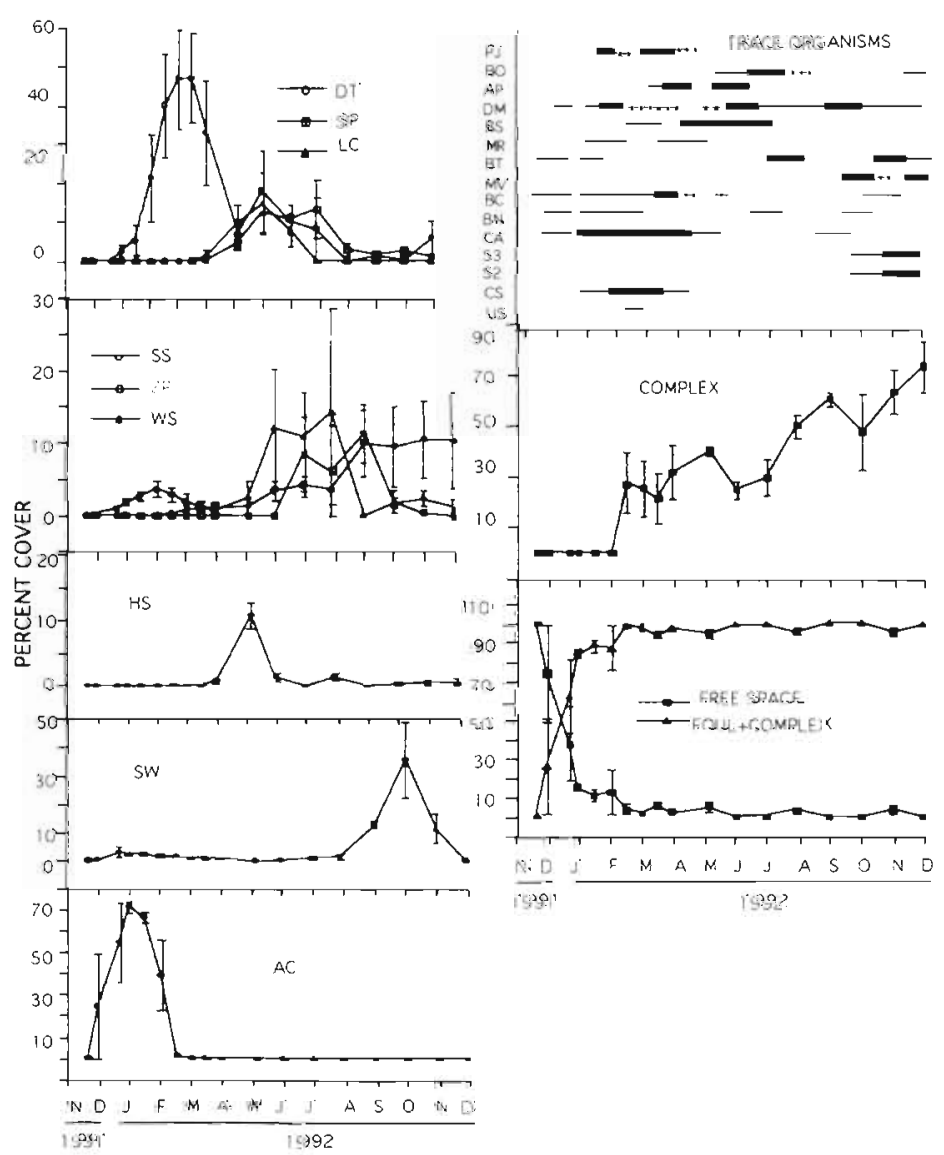

Fig. 3. Fluctuation of areal cover of sessile organisms on the sunlit faces of panels suspended in November 1991 and monitored until December 1992. For definitions of abbreviations see Table 1 . Vertical bars indicate $\mathrm{SD}(\mathrm{n}=4)$. Trace organisms are those that covered $<10 \%$ of the observed panel area; thin bars indicate $<1 \%$; thick bars show 1 to $5 \%$ and (") shows 5 to $10 \%$; complex represents total organic and inorganic matter on the panels including the remaining organisms; foul + complex shows total settlement 

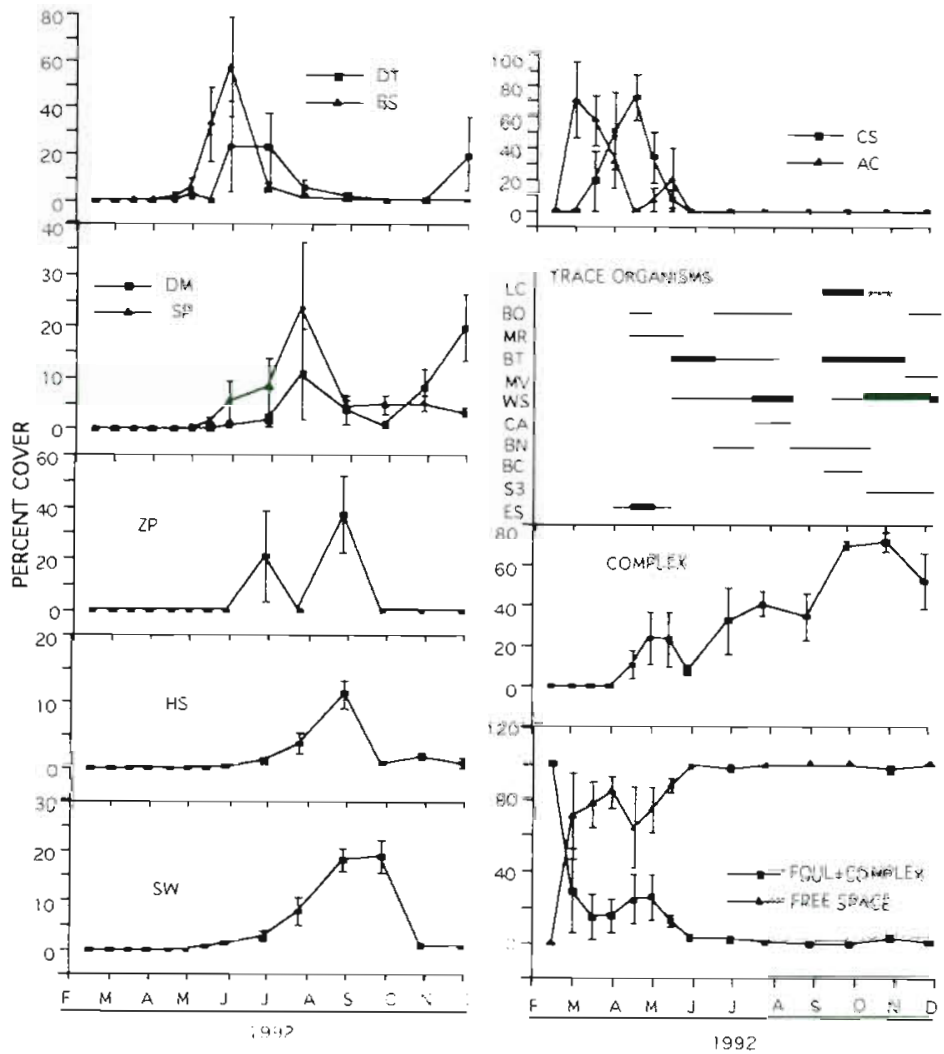

Fig. 4. Fluctuation of areal cover of sessile organisms on the sunlit faces of panels suspended in February 1992 and monitored until December 1992. Symbols and abbreviations as in Fig. 3

and serpulid worms during the initial period of community development. Even though colonial ascidians and bryozoans were present for a considerable period of time, neither of these organisms occupied as large an area as was found in the autumn initiated panels (Figs. 3 to 6 ).

\section{Summer series}

Panels initiated in summer were dominated by barnacles and serpulid worms in the initial phase; however, the colonial ascidians showed increased area cover towards the end of the study (Figs. 3 to 6).

\section{Relationship between the time of panel immersion and percentage area cover}

In order to ascertain the relationship between the time of panel suspension and species area cover, a 1 -tail $t$-test was carried out. This was done by comparing the percentage area cover of ascidians, bryozoans and other solitary invertebrates occupying panels initi- ated in different seasons when they became 2. 4 and 8 mo old (interseasonal comparison). The results showed no significant difference in area cover of any of the above 3 groups after 2 mo of panel suspension (Table 5). But, as time elapsed, a difference in percentage area cover could be detected, i.e. at 4 and 8 mo (Table 5). This showed the effect of timing of panel immersion and duration of panel exposure on the development and/or succession of sessile organisms.

\section{Interaction results}

Altogether, 7980 interspecific interactions were monitored. Results of overgrowth interactions recorded on panel surfaces after 4 mo and at the end of the study are given in Figs. 7 \& 8 , respectively. The competitive relationships after 4 mo and at the end of the study are given in Figs. $9 \& 10$, respectively. Comparison of the competitive relationships after 4 mo and at the end of the study showed considerable differences on panels suspended in autumn and winter, while spring panels did not show much variation. In the autumn initiated panels, after 4 mo of submersion the brown alga Colpomenia sinuosa occupied a higher position than the bryozoans, while the respective positions were reversed at the end of the study (Figs. $9 \& 10$ ). However, on both of these occasions the ascidians retained their position in the hierarchical order. Similarly, visible changes in the species hierarchy could be detected in the winter initiated panels. Meanwhile, a well-defined hierarchy could be detected on the panels after 4 mo of initiation, and a lack of hierarchy on the same panels could be seen at the end of the study.

With respect to the time of panel suspension, different orders of hierarchies could be detected (Figs. 9 \& 10). The results show clear evidence of reversed positions in the hierarchy depending on the time of panel submersion. The colonial ascidians competitively dominated in the species interactions and thus occupied the topmost position in the hierarchy in autumn and summer initiated panels. Reversals of positions of brown algae, sponges and bryozoans also could be detected in the autumn and winter initiated panels (Figs. $9 \& 10$ ). In addition, the reversed positions of sponges and brown algae in the hierarchy by the end of the study also document a clear example of time dependent competitive outcome on experimental panels. 


\section{Competitive relationships}

Competitive relationships among the sessile organisms which developed on panel surfaces suspended in different months and were analyzed after 4 mo and at the end of the study are given in Figs. $11 \& 12$. The competitive relationships resulted in hierarchy on panels suspended in all 4 seasons and observed after 4 mo of submersion. The autumn and summer initiated panels resulted in hierarchy at the end of the study, while a lack of hierarchy could be observed on panels exposed in winter and spring. In winter the competitive relationship resembled a network (Fig. 12)

\section{DISCUSSION}

\section{Species interaction and competitive hierarchies}

Sebens (1986) suggested that the ultimate aim of studies on interspecific competition is to explain community development and persistence of multispecies systems through time. The competitive hierarchies of taxonomic groups on panels suspended during 4 seasons were found to be different from one another (Figs. $9 \& 10$ ). The orders of species hierarchy were found to be different from those observed in Australia by Russ (1982) and on an earlier occasion at the present study area by Nandakumar et al. (1993). The competitive hierarchy observed in an earlier observation carried out during autumn (from September 1991 to January 1992) from the same locality showed the competitive dominance of colonial ascidians, especially Diplosoma mitsukurii, followed by sponges, bryozoans, brown algae, serpulid worms, and green algae (Nandakumar et al. 1993). A more or less similar type of hierarchy was reported from Australia by Russ (1982). However, on the panels suspended in autumn in the present observation, the hierarchy changed with the replacement of the second spot of sponges by bryozoans at the end of the study (Fig. 10) and by brown algae 4 mo after the panel initiation (Fig. 9). This change could be due to the change in time of panel initiation. In the earlier study, the panels were initiated in September 1991 and observed for a period of 4 mo (Nandakumar et al. 1993).
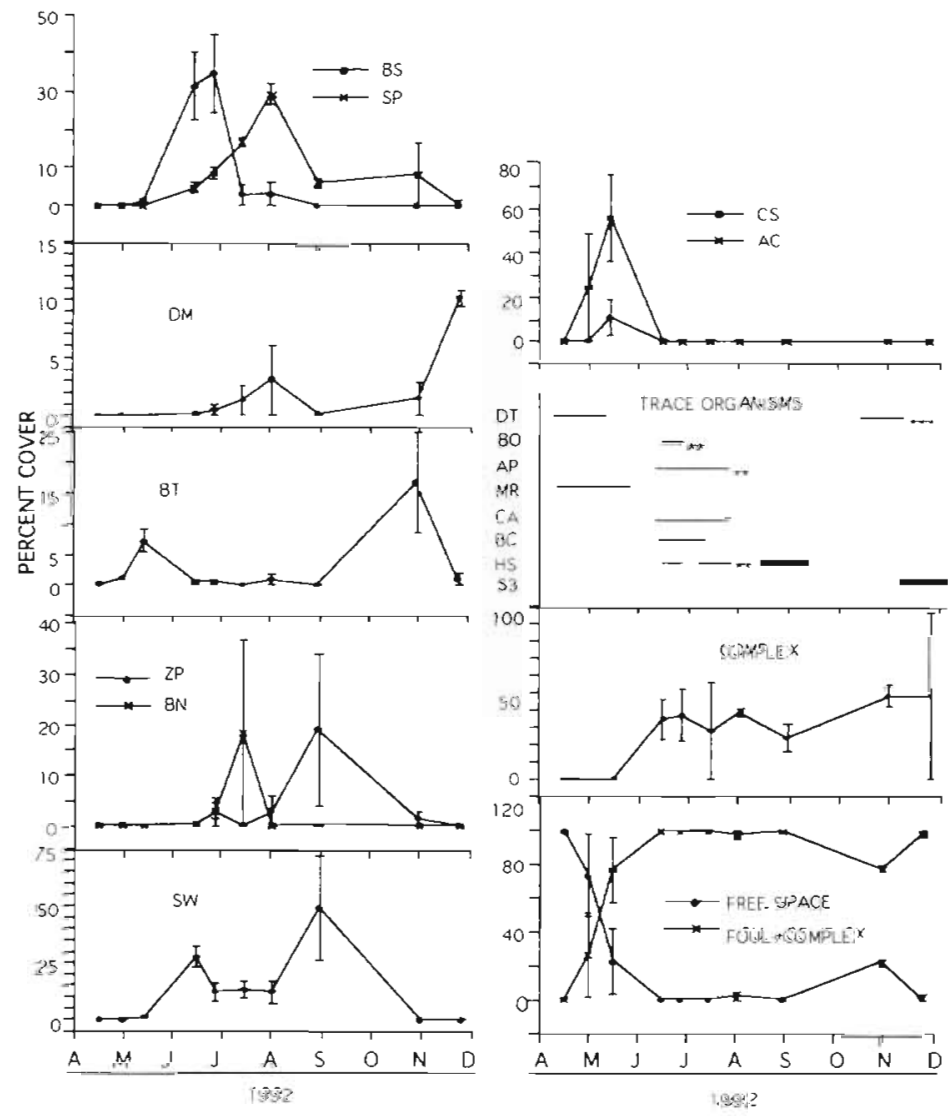

Fig. 5. Fluctuation of areal cover of sessile organisms on the sunlit faces of panels suspended in April 1992 and monitored until December 1992. Symbols and abbreviations as in Fig. 3
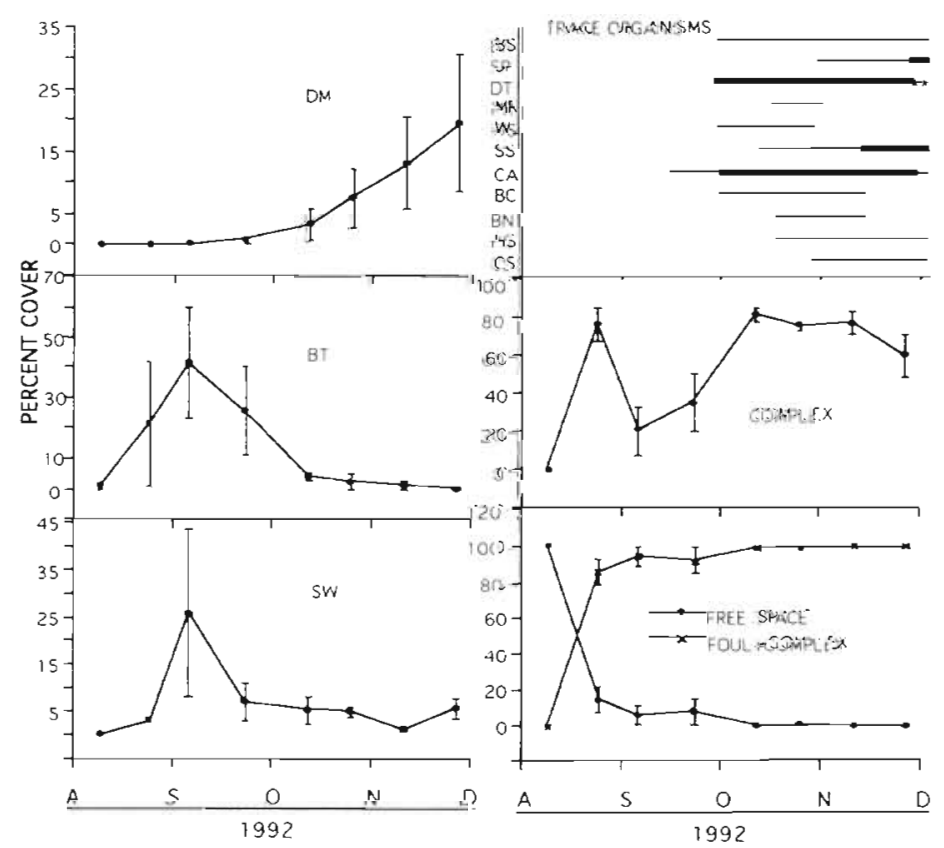

Fig. 6. Fluctuation of areal cover of sessile organisms on the sunlit faces of panels suspended in August 1992 and monitored until December 1992. Symbols and abbreviations as in Fig. 3 

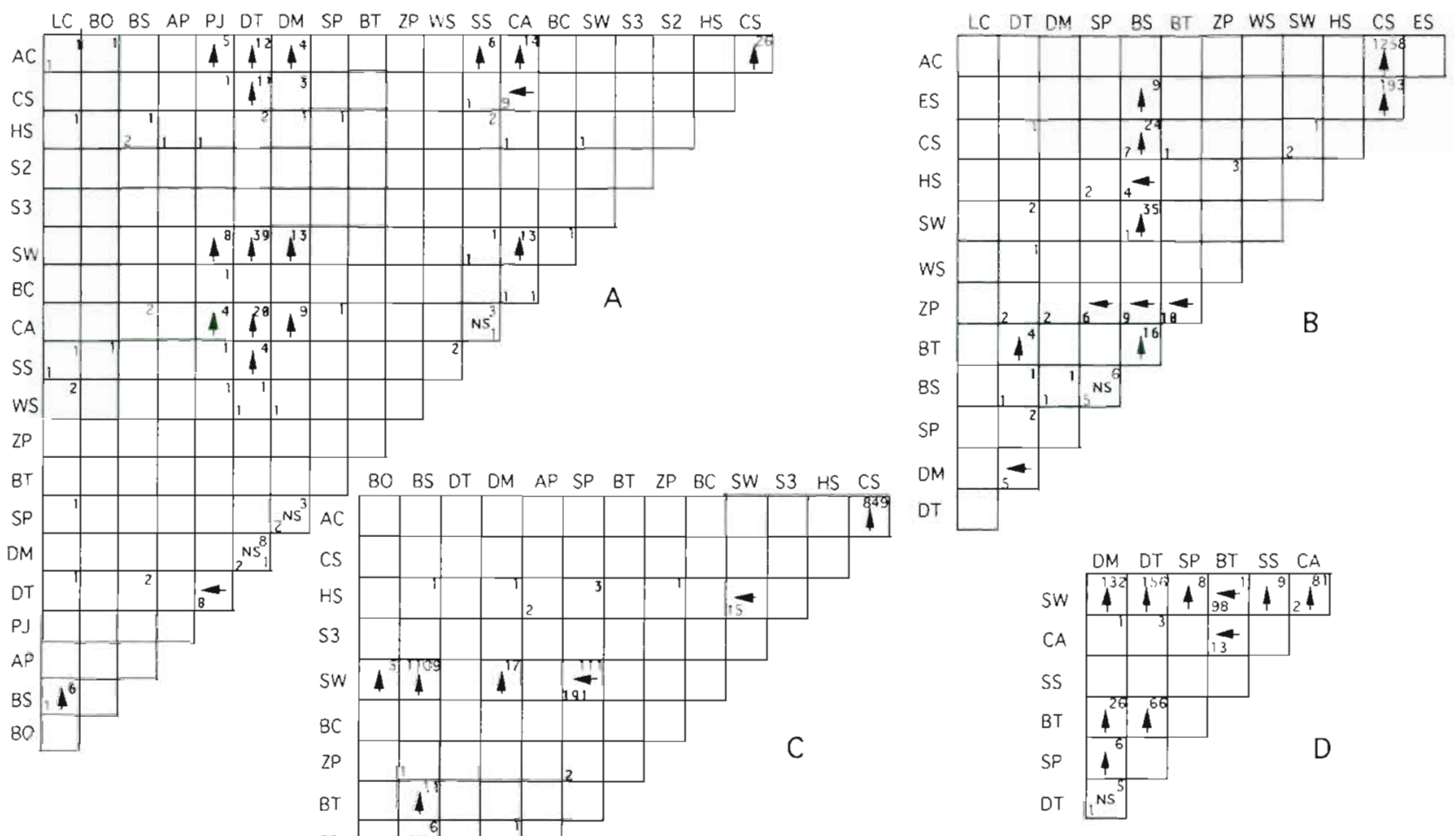

Fig. 7. Matrix showing the interaction results of dominant sessile organisms encountered on the sunlit surfaces of panels suspended in (A) November 1991, (B) February 1992, (C) April 1992, and (D) August 1992 and monitored after 4 mo of initiation. Species pairs interacted 4 or more times and covered more than $1 \%$ of the observed panel area tested using $\chi^{2}$ test. Arrow points to significant winner of the 2 species in each cell. Numbers in each cell indicate the results of interactions. Value in the upper right corner represents the win; at the bottom left corner, the loss of the species listed in the upper side of the matrix; at the bottom right corner the number of standoffs. NS: no significant success; blank column represents no interactions. For definitions of abbreviations see Table 1

Most of the earlier studies showed colonial ascidians as the most dominant organisms, occupying the topmost position in the hierarchical order. However, in the present study, this was not found to be true in some of the panel sets which were initiated in different periods of an year. In the present study, panels initiated in winter and spring showed the branching bryozoan Zoobotryon pellucidum as the competitively dominant species at the end of the first 4 mo of immersion (Figs. $11 \& 12$, Table 2). While the panels initiated in winter resulted in a lack of hierarchy at the end of the study, those initiated in spring resulted in a co-dominance of the bryozoan $Z$. pellucidum and the ascidian Botryllus schlosseri. Some earlier studies have also shown a strong relationship between the time of colonization of a species and its position in the order of hierarchy (Sutherland \& Karlson 1977. Sebens 1986)

In a classic study on the succession of fouling organisms on panels at Beaufort, North Carolina, USA,
Sutherland (1974) reported the existence of multiple stable points in a community. He also reported that the order of larval recruitment played an important role in determining the monopolizing species during the initial stages of community development. The present study also showed the existence of seasonal effect on the competitive relationship of sessile organisms (reversals of positions in the hierarchical order; Figs. 9 to 12 ). The order of hierarchy varied widely both between panels exposed in different seasons and with their exposure time/duration (Figs. $9 \& 10$ ). Various degrees of competence exhibited by the encrusting organisms such as encrusting bryozoans and colonial ascidians were primarily characterized by intransitive relationships (Jackson \& Buss 1975, Buss \& Jackson 1979, Rubin 1982). That is, a competitive network permits relatively high diversity levels in environments with low levels of disturbance. The present study area was a relatively well protected one with no strong wave action and/or disturbance from predators such as 

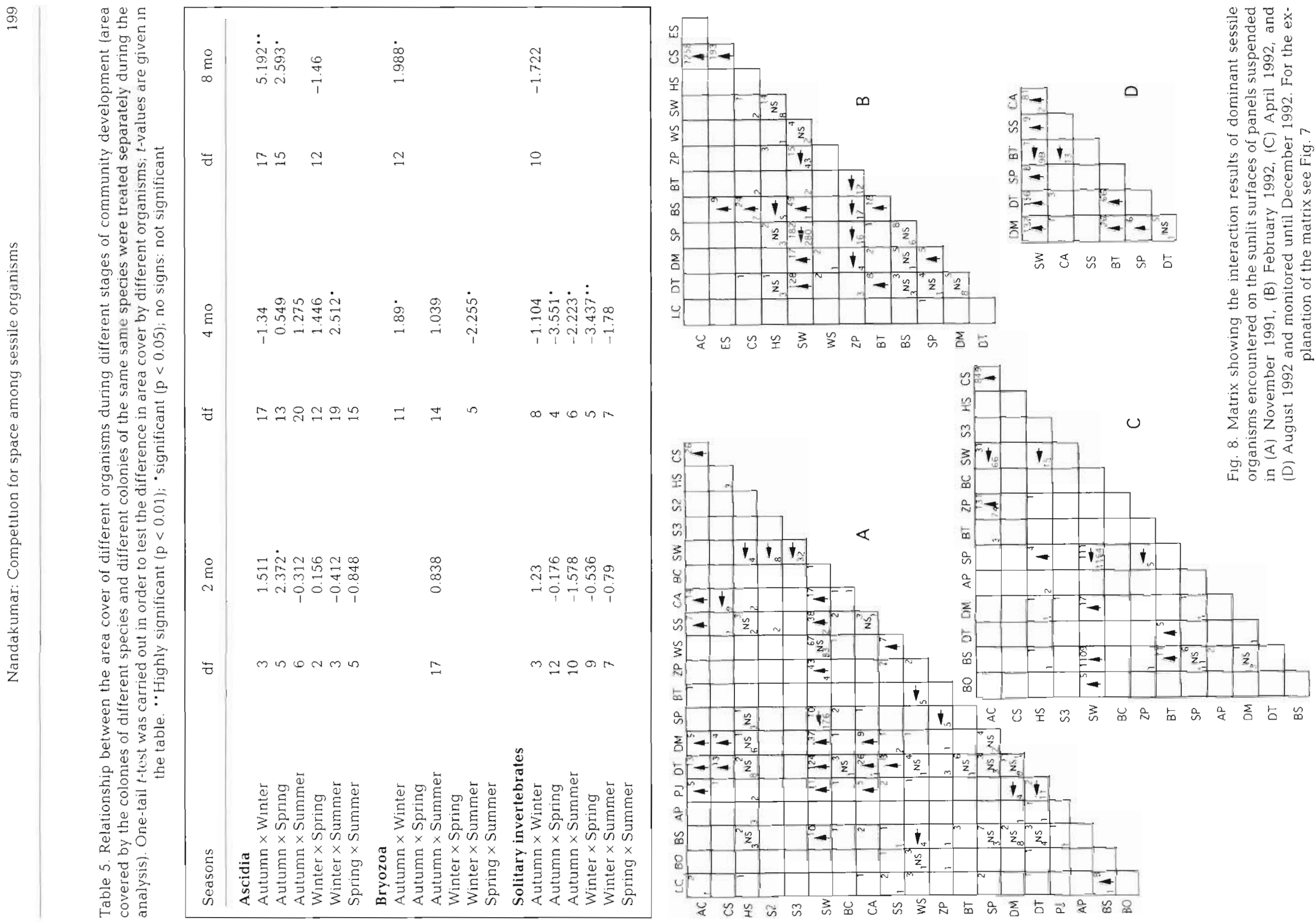


$\begin{array}{ccc}\begin{array}{c}\text { Autumn } \\ \text { initiated }\end{array} & \begin{array}{c}\text { Winter } \\ \text { initiated }\end{array} & \begin{array}{c}\text { Spring } \\ \text { initiated }\end{array} \\ \text { initiated } \\ \text { Ascidia }\end{array}$

Fig. 9. Order of hierarchy among the taxonomic groups of sessile organisims observed on panels initiated in different seasons after $4 \mathrm{mo}$ of initiation. Arrows point to the superior groups

sea urchins or crabs (Nandakumar 1993). Therefore, the probable reasons for this variation in the order of hierarchy could be attributed to the change in seawater temperature at the time of panel immersion (Fig. 2), and its impact on the biology and life cycles of various organisms. Lower seawater temperatures might have made the recruitment and growth of larvae of the better competitors, such as colonial ascidians and sponges, difficult.

In this locality, the seawater temperature recorded reached nearly $13^{\circ} \mathrm{C}$ during winter, and around $28^{\circ} \mathrm{C}$
Nov $\mathrm{A}$

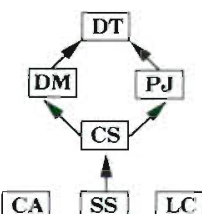

CA SS LC HS BO AP SP WS BS ZP AC SW $\mathrm{S2}$ S3 BC BT

APR A

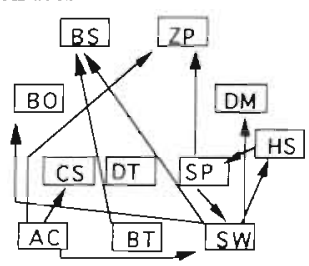

FEB A

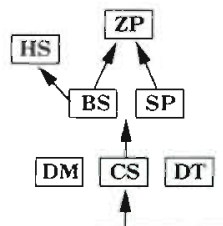

ES $\mathrm{BT}$ SW $\mathrm{AC}$

AUG A

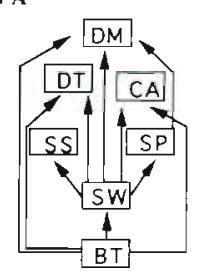

Fig. 11. Hierarchy observed on the panels after 4 mo of initiation. Charts are prepared from the results of $\chi^{2}$ analyses. Month of panel suspension is mentioned in the respective hierarchy charts. For definitions of abbreviations see Table 1

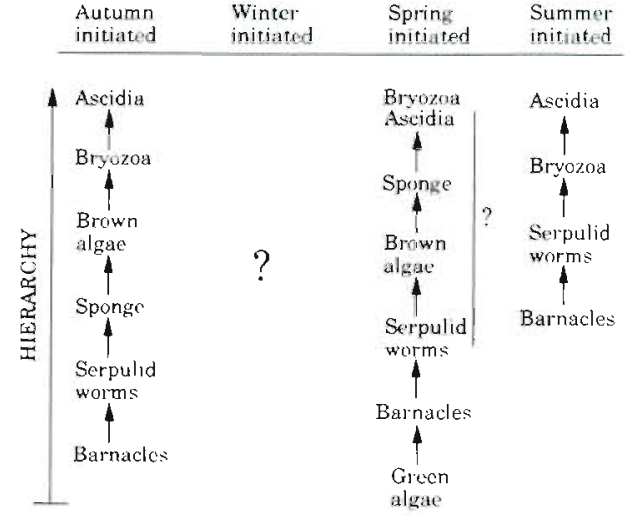

Fig. 10. Order of hierarchy among the taxonomic groups of sessile organisms observed on panels initiated in different seasons and monitored until the end of the study. Arrows point to the superior groups. ?: lack of clear competitive dominance or clear hierarchy

during summer (Fig. 2). The initial recruits to the panel surfaces during the cold seasons occupied a majority of the panel area and might have prevented the recruitment of fresh arrivals for a considerable period of time. This resistance of initial recruits to fresh arrivals and the slow growth and fast disappearance (Table 4) of the late recruits might have led to the co-dominance or lack of hierarchy on panels suspended in winter and spring (Nandakumar 1993). More or less similar observations (with respect to the resistance offered by initial recruits to latecomers) were made by Sutherland \&

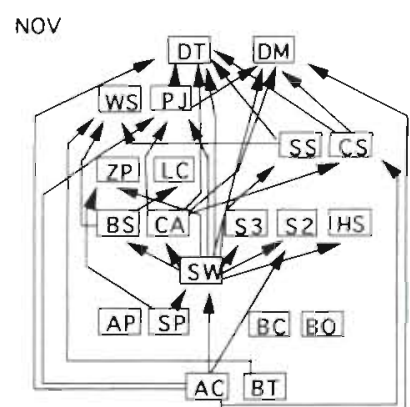

FEB

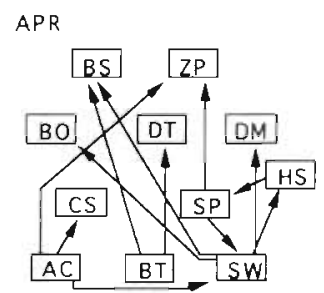

$A \cup G$

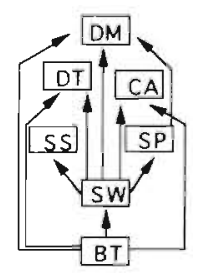

Fig. 12. Hierarchy observed on the panels at the end of the study. Charts are prepared from the results of $\chi^{2}$ analyses. Month of panel suspension is mentioned in the respective hierarchy charts. For definitions of abbreviations see Table 1 
Karlson (1977) from Beaufort Bay. In addition, organisms such as sponges and ascidians (Gordon 1972, Russ 1982, Sebens 1986) and bryozoans (Todd \& Turner 1988 i were reported to survive overgrowth for a considerable period of time. This survival ability of sessile organisms might also have contributed to the observed seasonal trend in the present study.

\section{Overgrowth interaction and its relationship to species dominance}

Biological interactions are considered to be one of the major factors determining the species composition in a given epifaunal community. Odum (1969) described succession as an orderly and directional process prone to physical disturbances and culminating in a stable climax. This paradigm was however challenged by Connell (1972). In another example, while studying the fouling community at Beaufort Bay, Sutherland (1974) reported the existence of multiple stable points which were mainly governed by the pattern of initial larval recruitment on a fresh substratum. In my study, I compared species dominance patterns (with respect to the area cover) to that of the outcome of competitive interactions. Even though the period of study was short as compared to many earlier studies on succession, the results appear to be in agreement with those of Sutherland (1974). That is, neither was the development of community unidirectional nor was the species dominance unimodal. But, the community was a multispecies dominated one, with the dominance of species of only short duration.

Species number increased significantly with time in the first 4 mo after panel immersion (Table 2). However, in the winter initiated panels, the peak was observed after 5 to 6 mo of panel immersion (Fig. 2). In all the panels, after attaining the peak, the species number reduced and fluctuated around an equilibrium. This pattern is in agreement with the results of Osman (1977, 1978) and Hirata (1987), but contradicts those of Schoener (1974). This pattern shows the rapid successional changes occurring in the initial stages of community development, mediated by intensive overgrowth interactions.

Some specific examples could be cited as to the importance of the competitive interactions which might have led to the elimination of species. In the autumn initiated panels, disappearance of the algal complex could be attributed to the overgrowth of the colonial ascidian Diplosoma mitsukurii; in the winter initiated panels, the disappearance of the algal complex could be due to the overgrowth by the brown alga Colpomenia sinuosa, and the disappearance of the colonial ascidian Botryllus schlosseri could be attrib- uted to the overgrowth of the branching bryozoan Zoobotryon pellucidum. At the same time, the disappearance of the colonial ascidian $D$. mitsukurii in the autumn initiated panels could not be attributed to overgrowth interactions because the interaction results showed $D$. mitsukurii as the competitively dominant species, not defeated by any other species. The results showed that the dynamics of serpulid worms in the panels were also arguable as far as the influence of overgrowth interactions are concerned.

Thus, community development and succession could be described as having multiple and short-lived species dominancy periods. Even though competitive interactions appear to be playing vital roles in governing the species composition at this locality, factors such as the initial invaders of the substratum, the time of panel initiation, and the duration of panel exposure prove to be very important in determining the composition, succession, and/or development of the sessile invertebrate community. Nevertheless, the seasonally dependent competitive relationships found in the present study among sessile organisms are highly interesting and show the importance of timing panel immersion and the pattern of initial recruitment on competitive relationships in these types of organisms.

Acknowledgements. 1 express my sincere gratitude to my advisors, Prof. Tauji Kikuchi and Dr Masao Tanaka, for their valuable suggestions and comments during this work. Valuable comments from 4 anonymous referees during the review process are also gratefully acknowledged. The Japanese Ministry of Science and Culture provided financial assistance. My wife, Dr K. R. Sreekumari, helped me with the preparation of the manuscript. This is Amakusa Marine Biology Laboratory, Kyushu University, contribution no. 392.

\section{LITERATURE CITED}

Anderson MJ, Underwood AJ (1994) Effects of substratum on the recruitment and development of an intertidal estuarine fouling assemblage. J exp mar Biol Ecol 184:217-236

Benayahu Y, Loya Y (1981) Competition for space among coral-reef sessile organisms at Eilata, Red Sea. Bull mar Sci 31:514-522

Best MA, Thorpe JP (1986) Feeding-current interactions and competition for food among the bryozoan epiphytes of Fucus serratus. Mar Biol 93:371-375

Buss LW (1979) Bryozan overgrowth interactions: the interdependence of competition for space and food. Nature 81 . $475-477$

Buss LW (1980) Competitive intransitivity and size frequency distributions of interacting populations. Proc natl Acad Sci USA 77:5255-5259

Buss LW (1990) Competition within and between encrusting clonal invertebrates. TREE 5:352-356

Buss LW, Jackson JBC (1979) Competitive networks: nontransitive competitive relationships in cryptic coral reef environments. Am Nat 113:223-234

Connell JH (1961a) Effects of competition, predation by Thais lapillus, and other factors on natural populations of the barnacle Balanus balanoides. Ecol Monogr 31:61-104 
Connell JH (1961b) The influence of interspecific competition and other factors on the distribution of the barnacle Chthalmalus stellatus. Ecology 42:710-723

Connell JH (1972) Community interactions on marıne rocky intertidal shores. A Rev Ecol Syst 3:169-192

Dayton PK (1971) Competition, disturbance and community organization: The provision and subsequent utilization of. space in a rocky intertidal community. Ecol Monogr 41. $351-389$

Gordon DP (1972) Biological relationship of an intertidal bryozoan population. J nat Hist 6:503-514

Greene CH, Schoener A (1982) Succession on marine hard substrata. A fixed lottery. Oecologia 55:289-297

Greene CH. Schoener A, Corets E (1983) Succession on marine hard substrata: the adaptive significance of solitary and colonial strategies in temperate fouling communities. Mar Ecol Prog Ser 13:121-129

Grosberg RK (1981) Competitive ability influences habitat choice in marine invertebrates. Nature 290:700-702

Harger JRE (1.972) Competitive ca-existence: maintenance of interacting associations of sea mussels Mytilus edulis and Mytilus californianus. Veliger 14:387-410

Harvell CD. Padilla DK (1990) Inducible morphology, heterochrony and size hierarchies in a colonial invertebrate monoculture. Proc natl Acad Sci USA 87:508-512

Hirata $T$ (1987) Succession of sessile organisms on experimental plates immersed in Nabeta Bay, lzu Peninsula, Japan. II. Succession of invertebrates. Mar Ecol Prog Ser $38: 25-35$

Jackson JBC (1977) Competition on marine hard substrata the adaptive significance of solitary and colonlal strategies. Am Nat 111:743-767

Jackson JBC (1979) Overgrowth competition between uncrusting cheilostome ectoprocts in a Jamascan cryptic reef environment. J Anim Ecol 48:805-823

Jackson JBC (1983) Biological determinants of present and past sessile animal distributions. In: Tevesz MJS, McCall TL (eds) Biotic interactions in recent and fossil benthic communities. Plenum Press, New York, p 39-120

Jackson JBC, Buss LW (1975) Allelopathy and spatial competition among coral reef invertebrates. Proc natl Acad Sci USA 72:5160-5163

Karande AA, Swami BS (1988) Overgrowth competitions amongst encrusting cheilostomes. Proc Indian Acad Sci (Anim Sci) 97:141-149

Kay AM, Keough MJ (1981) Occupation of patches in the epifaunal communities on pier pilings and the bivalve Pinna bicolor at Edithburgh, South Australia. Oecologia 48 $123-130$

Lang JC (1973) Interspecific aggression by scleractinian corals II. Why the race is not only to the swift. Bull mar Sci 21:260-279

Logan A (1984) Interspecific aggression in hermatipic corals from Bermuda. Coral Reefs 3:131-138

Lopez Gappa JJ (1989) Overgrowth competition in an assemblage of encrusting bryozoans settled on artificial substrata. Mar Ecol Prog Ser 51:121-130

Nandakumar K (1993) Interspecific competition for space among subtidal sessile organisms. PhD thesis, Kyushu University

Nandakumar K (1995) Competitive interactions among sessile organisms in Tomioka Bay, south Japan: importance of light conditions on the panel surface. Mar Biol 121 $713-719$

Nandakumar K, Tanaka M (1993) Interspecific competition among sessile invertebrates: a review. Publ Amakusa mar biol Lab Kyushu Univ 12:13-35
Nandakumar K. Tanaka M (1994a) Formation of giant buds in the cheilostome bryozoan Schizoporella serialis (Heller, 1867) during its interactions with the bryozoan Celleporaria aperta (Hinks, 1882). J exp mar Biol Ecol 183: $1-9$

Nandakumar K, Tanaka M (1994b) Effects of neighboring organisms on the growth of three intertidal encrusting cheilostome bryozoans. Mar Ecol Prog Ser 114:157-163

Nandakumar K, Tanaka M, Kikuchi T (1993) Interspecific competition of fouling organisms in Tomioka Bay, Japan. Mar Ecol Prog Ser 94:43--50

Odum EP (1969) The strategy of ecosystem development. Science 164:262-270

Okamura B (1986) Group living and the effects of spatial position in aggregations of Mytilus edulis. Oecologia 69: $341-347$

Osman RW (1977) The establishment and development of a marine epifaunal community. Ecol Monogr 47:37-63

Osman RW (1978) The influence of seasonality and stability on the species equilibrium. Ecology 59:383-399

Paine RT (1984) Ecological determinism in the competition for space. Ecology $65: 1339-1348$

Quinn JF (1982) Competitive hierarchies in marine benthic communities. Oecologia 54:129-135

Rubin JA (1982) The degree of intransitivity and its measurement in an assemblage of encrusting cheilostome bryozoa. J exp mar Biol Ecol 60:119-128

Rubin JA (1985) Mortality and avoidance of competitive overgrowth in encrusting bryozoa. Mar Ecol Prog Ser 23: $291-299$

Russ GR (1982) Overgrowth in a marine epifaunal community: competitive hierarchies and competitive networks. Oecologia 53:12-19

Schoener A (1974) Colonization curves for planar marine islands. Ecology 55:818-827

Schoener A, Greene CH (1981) Comparison between destructive and nondestructive sampling of sessile epibenthic organisms. Limnol Oceanogr 26:770-774

Sebens KP (1985) Community ecology in subtidal rock walls in the Culf of Maine, USA: small scale process and alternative community states. In: Moore PG, Seed R (eds) The ecology of rocky coasts. Hodder and Stoughton Educational, Sevenoaks, p 346-371

Sebens KP (1986) Spatial relationships among encrusting marine organisms in the New England subtidal zone. Ecol Monogr 56:73-96

Sokal RR, Rohlf FJ (1987) Introduction to biostatistics, 2nd edn. WH Freeman \& Co, New York

Stebbing ARD (1973a) Competition for space between the epiphytes of Fucus serratus L. J mar biol Ass UK 53: $247-261$

Stebbing ARD (1973b) Observations on colony overgrowth and spatial competition. In: Larwood GP (ed) Living and fossil bryozoa. Academic Press, London, p 173-183

Steneck RS, Hacker SD, Dethier MN (1991) Mechanisms of competitive dominance between crustose coralline algae: an herbivore-mediated competitive reversal. Ecology 72 : $938-950$

Sutherland JP (1974) Multiple stable points in natural communities. Am Nat 108:859-873

Sutherland JP, Karlson RH (1977) Development and stability of the fouling community at Beaufort, North Carolina. Ecol Monogr 47:425-446

Todd CD, Turner SJ (1988) Ecology of intertidal and subluttoral cryptic epifaunal assemblages. II. Nonlethal overgrowth of encrusting bryozoans by colonial ascidians. $\mathrm{J}$ exp mar Biol Ecol 115:113-1.26 
Turner SJ, Todd CD (1994) Competition for space in encrusting bryozoans assemblage: the influence of encounter angle, site and year. J mar biol Ass UK 74:603-622

Underwood AJ, Anderson MJ (1994) Seasonal and temporal aspects of recruitment and succession in an intertidal estuarine fouling assemblage. J mar biol Ass UK 74:563-584

This article was submitted to the editor
Underwood AJ, Jernakoff P (1981) Effects of interactions between algae and grazing gastropods on the structure of a low-shore intertidal algal community. Oecologia 48: $221-233$

Woodin SA, Jackson JBC (1979) Interphyletic competition among marine benthos. Am Zool 19:1029-1043

Manuscript first received: March 20,1995

Revised version accepted: July 5, 1995 